\title{
Biohydrogen Production from Simple Carbohydrates with Optimization of Operating Parameters
}

\author{
Petra Muri, Ilja Gasan Osojnik Črnivec, Petar Djinović and Albin Pintar* \\ Laboratory for Environmental Sciences and Engineering, National Institute of Chemistry, Hajdrihova 19, \\ SI-1001 Ljubljana, Slovenia \\ * Corresponding author: E-mail: albin.pintar@ ki.si \\ Tel.: +38614760 237; fax: +38614760460
}

Received: 29-10-2015

\begin{abstract}
Hydrogen could be alternative energy carrier and source for chemical and fuel synthesis due to its high energy content, sustainable technology and zero carbon emissions. In particular, conversion of organic substrates to hydrogen via dark fermentation process is of great interest. The aim of this study was fermentative hydrogen production using anaerobic mixed culture using different carbon sources (mono and disaccharides) and further optimization by varying several operating parameters ( $\mathrm{pH}$ value, temperature, organic loading, mixing intensity). Among all tested mono- and disacchari-

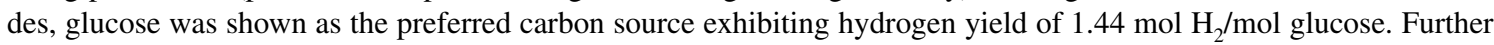
evaluation of selected operating parameters showed that the highest hydrogen yield $\left(1.55 \mathrm{~mol} \mathrm{H}_{2} / \mathrm{mol}_{\text {glucose }}\right)$ was obtained at the initial $\mathrm{pH}$ value of $6.4, \mathrm{~T}=37^{\circ} \mathrm{C}$ and organic loading of $5 \mathrm{~g} / \mathrm{L}$. The results show that lower hydrogen yield at all other conditions was associated with a redirection of metabolic pathways from butyric and acetic (accompanied by $\mathrm{H}_{2}$ production) to lactic (simultaneous $\mathrm{H}_{2}$ production is not mandatory) acid production. These results, therefore, represent an important foundation for the optimization and industrial-scale production of hydrogen from organic substrates.
\end{abstract}

Keywords: Biohydrogen; anaerobic sludge; operating parameters; carbon source; metabolic pathways

\section{Introduction}

Although biohydrogen is considered as one of the most promising energy carriers, many research topics focusing on renewable energy emphasize its on-site use in the chemical industry and refineries. At present, hydrogen is mainly produced by thermo-chemical processes, such as steam reforming of natural gas, coal gasification and oil reforming, i.e. processes with high operating temperature and pressures, that are based on fossil fuels. ${ }^{1}$ On the other hand, hydrogen can be produced from renewable resources through biological processes of photo-fermentation, bio-photolysis, dark fermentation, and/or water gas shift reaction.

Dark fermentative hydrogen production exhibits several advantages over other biological hydrogen production processes, as it enables higher conversion yields, a wider range of substrate utilization and requires no light. ${ }^{2}$ Fermentative hydrogen production from biomass can be attained either by mixed acidogenic microbial cultures or a pure culture of saccharolytic bacteria. Even though pure cultures have the potential to produce hydrogen at higher yields, ${ }^{3}$ these are not suitable for large-scale biohydrogen production due to requirements of frequent reactor sterilization, ongoing substrate hygienisation and process stability issues. In terms of scale-up and industrial application, use of mixed microbial consortia is therefore more practical than pure seed cultures, as the former allows simpler operation and utilization of a wider range of substrates.

Unhindered anaerobic microbial digestion (biomethane production) from carbohydrates can be described as a multi-step process consisting of hydrolysis, acidogenesis, acetogenesis, and methanogenesis involving five physiologically distinct groups of microorganisms working in a balanced symbiotic relationship. Firstly, hydrolytic bacteria hydrolyze organic matter into mono- and oligomers, which are fermented into volatile fatty acids, alcohols, $\mathrm{CO}_{2}$ and $\mathrm{H}_{2}$ by acidogenic bacteria. Further, acetogenic bacteria convert volatile fatty acids into acetate and hydrogen, while homoacetogenic bacteria convert $\mathrm{H}_{2} / \mathrm{CO}_{2}$ into acetate. In methanogenesis, methane is mainly produced either from acetate or $\mathrm{H}_{2} / \mathrm{CO}_{2}$ by acetoclastic 
and hydrogenotrophic methanogenic archea, respectively. ${ }^{4}$ As hydrogen is consumed by microorganisms such as homoacetogens, hydrogenotrophic methanogens and/or sulfate-reducing bacteria, high hydrogen yields can be achieved only by negative selection of hydrogen consumers. $^{5}$

Increasing the hydrogen yield in a mixed anaerobic microbial community is accomplished by inhibiting the growth of $\mathrm{H}_{2}$-consumers as well as maintaining satisfactory operating parameters for $\mathrm{H}_{2}$-producers, which can be achieved by pretreatment of an existing anaerobic microbiota that is readily available at various commercial biogas plants and wastewater treatment facilities. There are various reported inoculum pre-treatment methods including chemical (acidic, alkaline, chemicals inhibiting methanogenesis) and physical approaches (microwave, sonication, heat, aeration, freezing and thawing) and combinations thereof that control growth of $\mathrm{H}_{2}$-consumers as well as $\mathrm{H}_{2}$-producers. ${ }^{6,7}$ The listed treatment methods enable germination of spore-forming bacteria, such as Clostridium spp. and Bacillus spp., and elimination of non sporeforming bacteria, such as $\mathrm{H}_{2}$-consumers.

Large-scale hydrogen production still faces inefficiency of the production process, as metabolic pathways mainly result in the generation of energy-rich compounds, rather than hydrogen synthesis. ${ }^{8}$ Reaction pathways and thus hydrogen yield depend on operating conditions of anaerobic bioreactor, such as $\mathrm{pH}$ value, temperature, substrate concentration, nutrients, carbon source and mixing intensity. ${ }^{9,10}$ The variations of these factors can cause a shift in metabolic pathways of specific microorganisms as well as changes in entire microbial communities, ultimately leading to different fermentation types: ${ }^{1}$

- acetic acid fermentation,

$$
\mathrm{C}_{6} \mathrm{H}_{12} \mathrm{O}_{6}+2 \mathrm{H}_{2} \mathrm{O} \rightarrow 2 \mathrm{CH}_{3} \mathrm{COOH}+2 \mathrm{CO}_{2}+4 \mathrm{H}_{2}
$$

- propionic acid fermentation,

$$
\mathrm{C}_{6} \mathrm{H}_{12} \mathrm{O}_{6}+2 \mathrm{H}_{2} \rightarrow 2 \mathrm{CH}_{3} \mathrm{CH}_{2} \mathrm{COOH}+2 \mathrm{H}_{2} \mathrm{O}
$$

- butyric acid fermentation, and/or

$$
\mathrm{C}_{6} \mathrm{H}_{12} \mathrm{O}_{6} \rightarrow \mathrm{CH}_{3} \mathrm{CH}_{2} \mathrm{CH}_{2} \mathrm{COOH}+2 \mathrm{CO}_{2}+2 \mathrm{H}_{2}
$$

- ethanol fermentation.

$$
\mathrm{C}_{6} \mathrm{H}_{12} \mathrm{O}_{6} \rightarrow 2 \mathrm{CH}_{3} \mathrm{CH}_{2} \mathrm{OH}+2 \mathrm{CO}_{2}
$$

As it arises from reactions (1) - (4), hydrogen is generated in acetic acid, butyric acid and ethanol fermentations. A maximum of $4 \mathrm{~mol} \mathrm{H}_{2} / \mathrm{mol}$ glucose is obtained when acetate is the end product of fermentation, and 2 mol $\mathrm{H}_{2} / \mathrm{mol}$ glucose is produced in the case of butyrate. Reduced fermentation end products, such as ethanol and other alcohols, contain additional $\mathrm{H}$ atoms not present in the corresponding carboxylic acids, which imply that alcohol production gives correspondingly lower hydrogen yields while propionate fermentation is considered as $\mathrm{H}_{2}$ consuming pathway. As such, redirection of metabolic pathways towards acetate and butyrate production maximizes hydrogen yield. ${ }^{12}$

Since the fermentation performance depends on several factors, it is important to systematically evaluate influence of different parameters on metabolic pathways. Despite a considerable number of research papers include optimization of hydrogen production, some of the abovementioned operational parameters are not fully documented. The goal of this study was therefore to identify influence of various operating parameters on hydrogen production and to evaluate the feasibility of the dark fermentative hydrogen production. Moreover, metabolic pathways and consequently distribution of the end products depend also on substrate used. Screening different monoand disaccharides that are lignocellulosic biomass hydrolysates being available in various waste materials, such as wood and liquefied wood, woody crops, agricultural wastes and a host of others, will therefore represent an important foundation for the industrial scale-up of biohydrogen production process.

\section{Experimental}

\section{1. Inoculum}

The inoculum used in this study was obtained from the anaerobic digester treating waste sludge from municipal wastewater treatment plant operating in the mesophilic temperature conditions. The collected sludge was filtered through a sieve (Retsch, $\mathrm{S} / \mathrm{N} 07039992, d_{\text {mesh }}=2.8 \mathrm{~mm}$ ) to remove large solid particles and then stored at $4{ }^{\circ} \mathrm{C}$. Prior to each experiment, inoculum was stabilized at 37 ${ }^{\circ} \mathrm{C}$ until the concentration of lactic acid in inoculum reached concentration lower than $2 \mathrm{mg} / \mathrm{L}$. Table 1 summarizes the characteristics of inoculum used in the present study. After studying an influence of initial $\mathrm{pH}$ value of inoculum on hydrogen yield, all further experiments were conducted at an optimal $\mathrm{pH}$ value for hydrogen production. For this purpose, $\mathrm{pH}$ value of inoculum was adjusted to 5.7 using $4 \mathrm{M} \mathrm{HCl}$, which after aeration with nitrogen and argon increased to 6.4 .

Table 1. Characteristics of anaerobic sludge used as inoculum.

\begin{tabular}{lc}
\hline Parameter & Value \\
\hline Density $(\mathrm{g} / \mathrm{mL})$ & $0.99 \pm 0.05$ \\
pH value $(/)$ & $7.72 \pm 0.11$ \\
TS $(\mathrm{g} / \mathrm{kg})$ & $34.87 \pm 6.59$ \\
TVS $(\mathrm{g} / \mathrm{kg})$ & $24.62 \pm 5.03$ \\
TVS $(\%)$ & $70.61 \pm 5.28$ \\
C/H/N/S (wt. \%) & $34.7 \pm 1.8 / 4.9 \pm 0.4 / 5.5 \pm 1.7 / 1.6 \pm 1.3$ \\
\hline
\end{tabular}




\section{2. Experimental set-up}

Experiments were performed in an Automatic Methane Potential Test System (Bioprocess Control, model AMPTS II) equipped with a water bath and 15 glass reactors with a volume of $600 \mathrm{~mL}$ each. Each reactor was connected to a mechanical agitator enabling various mixing options. Reactors were sealed with tubing that led produced gas to sensor chambers, where cumulative production of biogas was measured by flow-through liquid displacement cells. The reactors were connected to the multichannel automatic valve, which enabled real-time analysis of gas phase by means of a gas chromatograph.

The bioreactors operated for $24 \mathrm{~h}$ with the working volume of $400 \mathrm{~mL}$, incubation temperature of $37^{\circ} \mathrm{C}$ and a stirring speed of $200 \mathrm{rpm}$. Inoculum was diluted with water in a ratio of $3: 1$. In all experiments, the mixtures were incubated in two parallel sets of batch reactors under identical experimental conditions. Prior to incubation, fermentation mixture and headspace were flushed with $\mathrm{N}_{2}(10$ min, $500 \mathrm{~mL} / \mathrm{min})$ and $\operatorname{Ar}(5 \mathrm{~min}, 500 \mathrm{~mL} / \mathrm{min})$, respectively, to attain anaerobic conditions.

When studying an influence of operating temperature on hydrogen production, batch fermentation tests were carried out in a 1000-mL glass reactor (Lenz, model LF 100) equipped with a heating jacket. The $\mathrm{pH}$ value was kept constant during the fermentation using a $\mathrm{pH}$ control unit consisting of $\mathrm{pH}$ electrode (Hamilton, model Easyferm food 325) and titrator (Metrohm, model 718 STAT Titrino). Cumulative volume of biogas produced was measured by means of the AMPTS system. Biohydrogen production was studied at temperatures of $24,30,37,40$, 45 and $55^{\circ} \mathrm{C}$ and working volume of $750 \mathrm{~mL}$.

\section{3. Effect of Operating Parameters (pH Value, Temperature, Organic Loading, Mixing Intensity) on Fermentation Types and Biohydrogen Production}

To study an influence of $\mathrm{pH}$ value on metabolic pathways and hydrogen production, $\mathrm{pH}$ value in reactors varied from 4.8 to 7.4 with a regular increment of 0.5. After obtaining an optimal $\mathrm{pH}$ value, biohydrogen production was evaluated at various temperatures specified above. Further, an influence of organic loading with various initial concentrations of glucose was studied $(1,2.5,5,10$, 15 and $30 \mathrm{~g} / \mathrm{L}$ ). An operating parameter examined as well in this study was mixing intensity, based on Reynolds number defined by the following equation:

$$
R e=\frac{\rho \circ L}{\sharp}
$$

where $\rho\left(\mathrm{g} / \mathrm{cm}^{3}\right)$ is density of inoculum, $v$ (rps) is rotation per second, $L(\mathrm{~cm})$ is a linear dimension of stirrer and $\mu$ $(\mathrm{g} / \mathrm{s} \mathrm{cm})$ is viscosity of inoculum. As the reaction mixture is considered to be fully turbulent when Re is 10.000 , mixing intensity in the anaerobic reactors was examined at the following Re numbers: 0, 500, 1.000, 2.000 and 10.000 .

During incubation, composition of gas phase, temporal concentration of carbon source and VFA were determined.

\section{4. Effect of Carbon Source on Biohydrogen Production}

In order to determine preferable carbon source of tested seed culture, different mono- (D-fructose (Sigma-Aldrich), D-galactose (Merck), D-glucose (Sigma-Aldrich), D-ribose (Sigma-Aldrich), D-xylose (Merck)) and disaccharides (D-lactose monohydrate (Merck) and D-sucrose (Sigma-Aldrich)) were examined.

\section{5. Analytical Methods}

Composition of gas phase was determined by means of a Micro GC Analyzer (Agilent Technologies, model 490) equipped with a TCD detector calibrated for hydrogen, nitrogen, methane, carbon dioxide and hydrogen sulfide. CP-MolSieve 5A column (Agilent) with Ar as a carrier gas was used to analyze hydrogen, nitrogen and methane, while carbon dioxide and hydrogen sulfide were analyzed using a CP-PoraPLOT U column (Agilent) with $\mathrm{He}$ as a carrier gas. The temperature of the injector and column were kept at 80 and $100{ }^{\circ} \mathrm{C}$, respectively. Volatile fatty acids (VFA), sugars and ethanol were determined by high performance liquid chromatography using an HPLC apparatus (Agilent Technologies, model 1260 Infinity) equipped with a cation-exchange Hi-Plex H column $(3.0 \times$ $5.0 \mathrm{~mm}, 8 \mu \mathrm{m})$. The column temperature was set to $50{ }^{\circ} \mathrm{C}$. Samples were eluted using sulfuric acid $(0.01 \mathrm{M})$ at a flow rate $0.6 \mathrm{~mL} / \mathrm{min}$. Volatile fatty acids were analyzed by UV detection at $210 \mathrm{~nm}$, while the concentration of ethanol and sugars were determined by using RI detector kept at $35{ }^{\circ} \mathrm{C}$.

\section{Results and Discussion}

\section{1. Influence of Initial pH Value on Hydrogen Production}

In order to validate effectiveness of acid pretreatment on non spore-forming bacteria and to assess optimal $\mathrm{pH}$ value for hydrogen production, a set of batch experiments with initial $\mathrm{pH}$ values equal to $4.8,5.3,5.8,6.4$, 6.8 and 7.4 (stabilized at the following exact values at the beginning of the process: $4.3,4.8,5.3,5.7,6.4$ and 6.9 , retrospectively) was conducted at $\mathrm{T}=37^{\circ} \mathrm{C}$ using glucose as a substrate. The operating initial $\mathrm{pH}$ value was shown to have a significant influence on several aspects of the 
a)

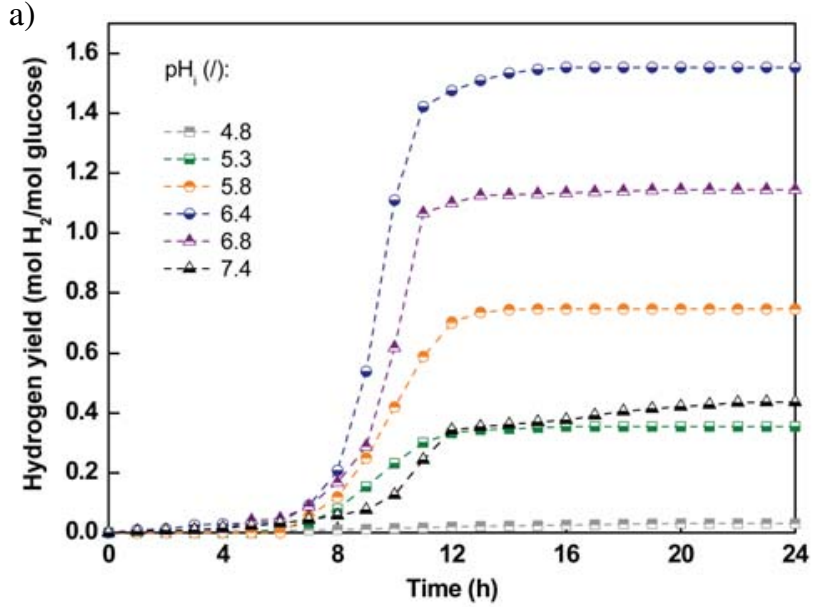

b)

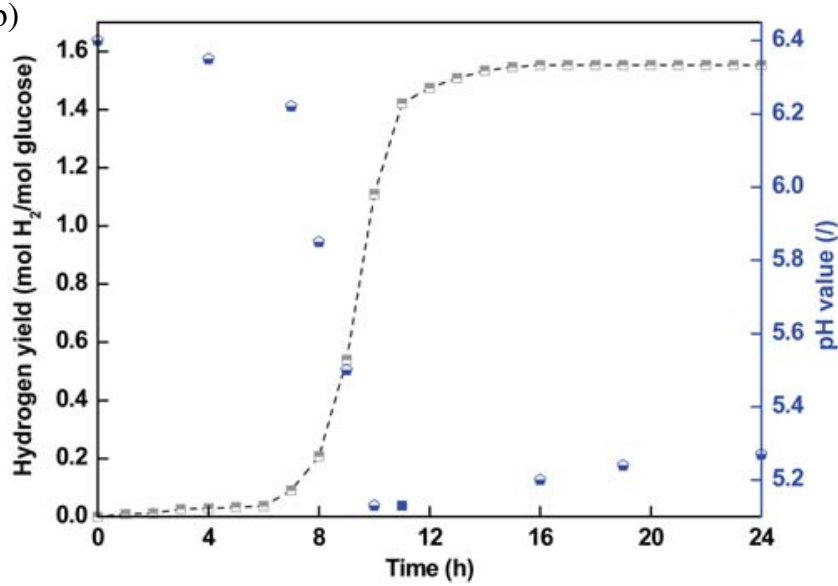

Figure 1. Effect of different initial $\mathrm{pH}$ values of fermentation broth on hydrogen yield (a) and change of $\mathrm{pH}$ value during hydrogen production (b). Lines show trends.

hydrogen production, such as cumulative hydrogen production, hydrogen production rate, hydrogen yield and duration of lag phase. As one can see in Table 2 and Figure 1 , the highest hydrogen production rate and hydrogen yield were obtained in the test mixture with the initial $\mathrm{pH}$ value of $6.4\left(91 \mathrm{NmL} / \mathrm{h}\right.$ and $1.55 \mathrm{~mol} \mathrm{H}_{2} / \mathrm{mol}$ glucose, respectively). Associated cumulative hydrogen production determined at this $\mathrm{pH}$ value was $346 \mathrm{NmL}$. Lower hydrogen production levels occurred in test mixtures with initial $\mathrm{pH}$ values below 5.8, as low $\mathrm{pH}$ values are known to suppress hydrogenase activity. ${ }^{13}$ By further lowering $\mathrm{pH}$ value of the fermentation broth to 4.8 , hydrogen production rate and hydrogen yield decreased to only $0.34 \mathrm{NmL} / \mathrm{h}$ and $0.03 \mathrm{~mol} \mathrm{H}_{2} / \mathrm{mol}$ glucose, respectively. Duration of the lag phase was found to increase below the initial $\mathrm{pH}$ value of 6.4 and increase above the same initial environmental condition. For initial $\mathrm{pH}$ values between 5.3-6.8, duration of the lag phase was in the range of 6.5-7.2 h. Fermentation at initial $\mathrm{pH}$ values of 4.8 and 7.4 exhibited longer lag phases being 8.1 and $9.2 \mathrm{~h}$, respectively. Longer lag phase at the lowest examined initial $\mathrm{pH}$ value (i.e. 4.8) and negligible production of hydrogen defines extreme environmental conditions for used anaerobic microbiota, while long lag phase at the highest initial $\mathrm{pH}$ value (i.e. 7.4) together with trace amounts of methane detected in the gas phase, already indicates the initiation of methanogenesis.

\section{2. Influence of Initial pH Value on Metabolic Pathways and Substrate Degradation}

Environmental $\mathrm{pH}$ value has been a widely investigated operating parameter that determines dark fermentative hydrogen production, since it affects both hydrogenase activity and metabolic pathways. In the present study, the main metabolic products were found to include butyrate, acetate, lactate, propionate, formate, valerate, citrate, maleate, malonate, succinate and ethanol, deriving from multiple fermentation pathways that were likely overlapping and competing during the occurrence of the studied process.

For the test mixture with the initial $\mathrm{pH}$ value equal to 4.8 , total concentration of volatile fatty acids was 2207 $\mathrm{mg} / \mathrm{L}$, of which $1995 \mathrm{mg} / \mathrm{L}$ was attributed to lactic acid. Low hydrogen yield obtained at this initial $\mathrm{pH}$ value (Table 2) appears to be consistent with the fact that the reaction step of lactic acid formation is not involved in hydrogen production scheme. Analysis of glucose concentrationtime profile at this $\mathrm{pH}$ value showed poor efficiency of substrate degradation, as final glucose concentration in the fermentation broth decreased from 4.86 to $1.94 \mathrm{~g} / \mathrm{L}$ only.

The highest hydrogen production at the initial $\mathrm{pH}$ value of 6.4 showed that glucose was mainly degraded via

Table 2. Performance of hydrogen production by anaerobic sludge fermentation at different initial $\mathrm{pH}$ values.

\begin{tabular}{lcccccc}
\hline Parameter & \multicolumn{5}{c}{ Initial pH value $(/)$} \\
& $\mathbf{4 . 8}$ & $\mathbf{5 . 3}$ & $\mathbf{5 . 8}$ & $\mathbf{6 . 4}$ & $\mathbf{6 . 8}$ & $\mathbf{7 . 4}$ \\
\hline Duration of lag phase $(\mathrm{h})$ & $8.1 \pm 0.3$ & $7.2 \pm 0.2$ & $7.0 \pm 0.1$ & $6.5 \pm 0.2$ & $6.8 \pm 0.2$ & $9.2 \pm 0.2$ \\
Cumulative $\mathrm{H}_{2}$ production $(\mathrm{NmL})$ & $6 \pm 3$ & $73 \pm 11$ & $152 \pm 16$ & $346 \pm 20$ & $258 \pm 18$ & $95 \pm 15$ \\
Maximal $\mathrm{H}_{2}$ production rate $(\mathrm{NmL} / \mathrm{h})$ & $0.34 \pm 0.08$ & $15 \pm 3$ & $28 \pm 2$ & $91 \pm 3$ & $65 \pm 3$ & $18 \pm 2$ \\
$\mathrm{H}_{2}$ yield $\left(\mathrm{mol} \mathrm{H}_{2} / \mathrm{mol}\right.$ glucose) & $0.03 \pm 0.01$ & $0.36 \pm 0.06$ & $0.75 \pm 0.07$ & $1.55 \pm 0.08$ & $1.14 \pm 0.08$ & $0.44 \pm 0.07$ \\
\hline
\end{tabular}


butyric and acetic acid fermentation pathways. These results suggest that the chemical treatment of inoculum at this $\mathrm{pH}$ value successfully enriched hydrogen producing endospore-forming bacteria. Despite taxonomical confirmation of presumptive Clostridium genus was not identified, it is well known that carbohydrate fermentation by Clostridium species produces mainly butyrate and acetate as primary soluble metabolites. ${ }^{14}$ As reported by several authors, high hydrogen yield was associated with butyric acid formed in excess of acetic acid as main metabolic
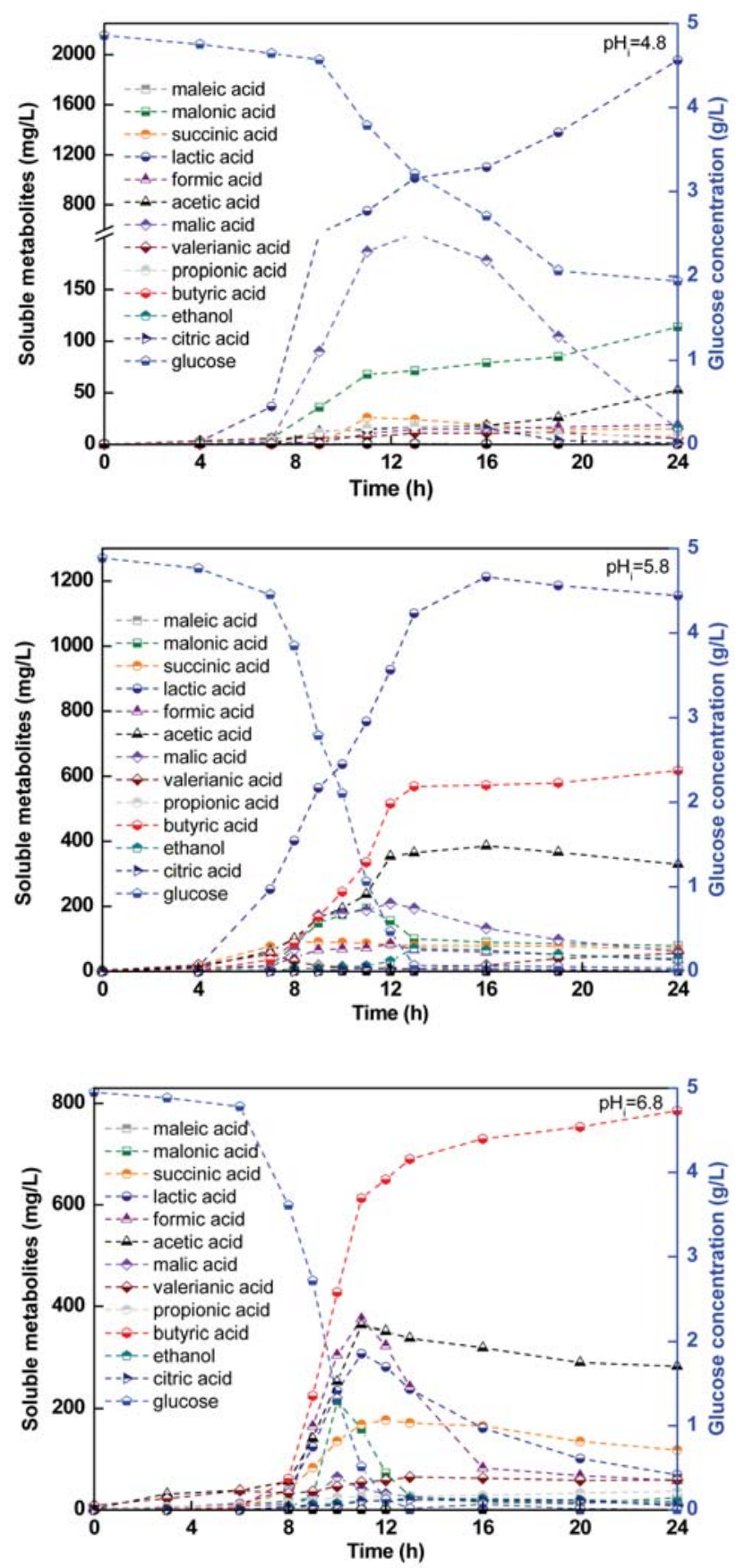

products. ${ }^{15}$ However, in our study the highest hydrogen yield resulted in dominant production of butyric acid (940 $\mathrm{mg} / \mathrm{L}$ ) over acetic acid (414 mg/L) (Figure 2), which is in accordance with the findings of Tang et al. ${ }^{16}$ and Guo et al. ${ }^{17}$ This divergence arises from the complexity of metabolic pathways in the mixed culture, as acetic acid can also be produced by hydrogen consuming bacteria during homoacetogenesis. There are however contradictory studies on hydrogen consumption by homoacetogens during the dark fermentative hydrogen production. In a paper
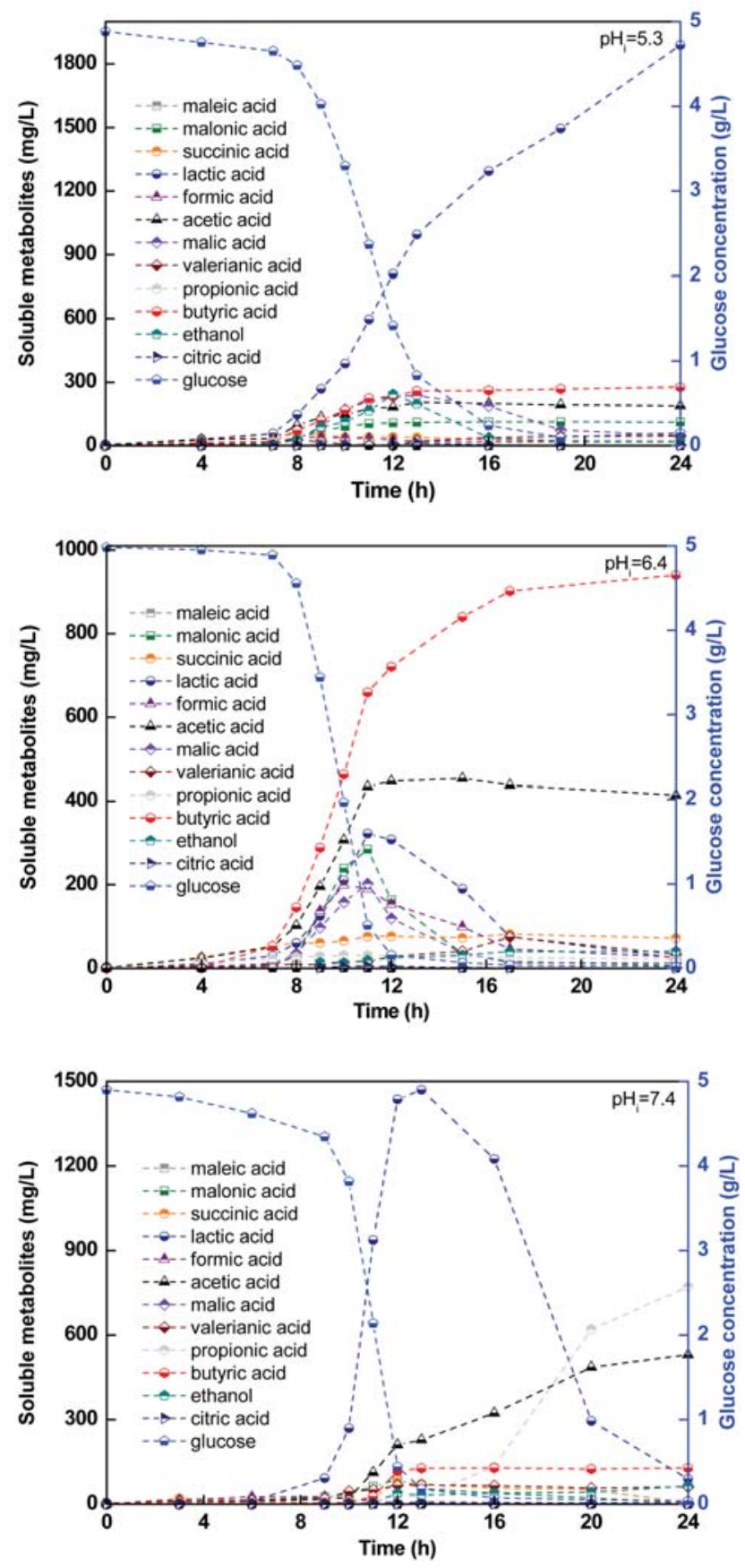

Figure 2. Time course profiles of soluble metabolites distribution (\%) and glucose degradation for different initial pH values of fermentation broth. Lines show trends. 
published by Kraemer and Bagley, ${ }^{18} \mathrm{H}_{2}$ consumption was accounted to decrease hydrogen yield for 2-11\%. In another study, homoacetogenesis was completely suppressed by reduction of HRT from 24 to 8 and $4 \mathrm{~h} .{ }^{19}$ Yet Saady et al. ${ }^{20}$ reported a decrease in hydrogen yield from 3.1 to 2.2 mol $\mathrm{H}_{2} /$ mol glucose due to homoacetogenesis.

In experiments where lactic acid largely prevailed among soluble metabolites, low hydrogen yields were observed. For initial $\mathrm{pH}$ values of 5.8, 5.3 and 4.8, concentrations of lactic acid measured at the end of runs were considerable, namely 1155,1889 and $1955 \mathrm{mg} / \mathrm{L}$, respectively. The obtained results proved a shift in metabolic pathways, as it is known that e.g. hydrogen producer Clostridium tyrobutyricum ATCC 25755 switches from butyric acid formation to the production of lactic and acetic acid when $\mathrm{pH}$ value decreases below $6.3 .^{8}$ In a study performed by Zhu and Yang, ${ }^{21}$ metabolic shift in C. tyrobutyricum was associated with $\mathrm{pH}$ effects on the expression levels of various acid-forming enzymes. As a consequence, formation of higher quantities of lactic acid resulted also in low hydrogen yields; for initial $\mathrm{pH}$ values of 4.8, 5.3 and 5.8, we namely obtained hydrogen yields of $0.03,0.36$ and $0.75 \mathrm{~mol} \mathrm{H}_{2} / \mathrm{mol}$ glucose, respectively. At the initial $\mathrm{pH}$ value equal to 6.8, the final concentration of lactic acid was $70 \mathrm{mg} / \mathrm{L}$, corresponding to hydrogen yield of $1.14 \mathrm{~mol}$ $\mathrm{H}_{2} /$ mol glucose. Even though the concentration of lactic acid at the end of fermentation reached only $89 \mathrm{mg} / \mathrm{L}$ for the experiment with the initial $\mathrm{pH}$ value of 7.4, its high concentration during the exponential phase (increase in the range of 91-1470 mg/L) leads to low hydrogen yield (0.44 $\mathrm{mol} \mathrm{H}_{2} / \mathrm{mol}$ glucose). Concurrent with decreasing concentration of lactic acid in stationary phase, concentrations of acetic and propionic acids increased. This could be due to the possible involvement of Propionibacterium that is addressed to convert lactate into propionate and acetate. ${ }^{22}$

Propionic acid was also an observed metabolic product, although significant concentrations of this compound were measured only at the initial $\mathrm{pH}$ value of 7.4. This could be supported by findings that propionic acidproducing bacteria grow faster at neutral $\mathrm{pH}$ values. ${ }^{23}$

As illustrated in Figures 2 and 3, part of substrate oxidation reactions followed the tricarboxylic acid (TCA)
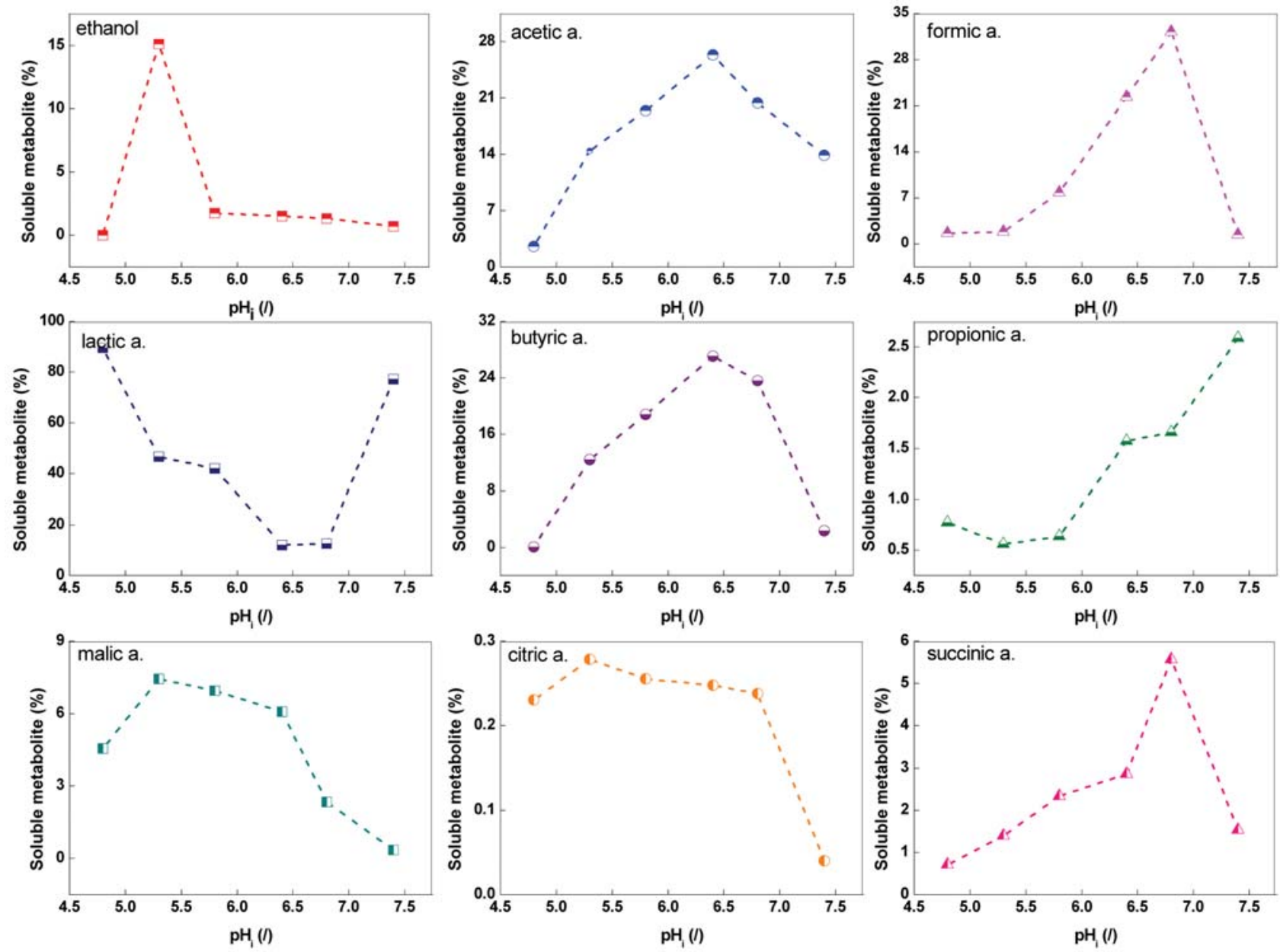

Figure 3. Soluble metabolites distribution (\%) on the end of exponential phase for different initial pH values of fermentation broth. Lines show trends. 
cycle. Citric acid was detected in the present study in low concentrations $(<20 \mathrm{mg} / \mathrm{L})$ for all initial $\mathrm{pH}$ values examined. More abundant were succinic and malic acid. We could observe that increasing $\mathrm{pH}$ value until 6.8 enhances production of succinic acid, while at further increase of $p$ $\mathrm{H}$ values the extent of its production decreases. On the other hand, the concentration of malic acid at the end of exponential phase appears to be similar for initial $\mathrm{pH}$ values of 4.8-6.4 (215 $\pm 15 \mathrm{mg} / \mathrm{L})$, while its concentration for initial $\mathrm{pH}$ values of 6.8 and 7.4 drops to 64 and $8 \mathrm{mg} / \mathrm{L}$, respectively. Based on these observations, it can be concluded that initial $\mathrm{pH}$ values of 5.3-6.8 increase the flow of glucose oxidation through the TCA cycle, while its further increase causes a decrease in the formation of TCA cycle metabolites. This could be supported by the findings that microorganisms participating in the TCA cycle inhabit environments with low $\mathrm{pH}$ values.

\section{3. Influence of Organic Loading}

To study an influence of organic loading on the process under consideration, anaerobic bioreactors operated at organic loadings of $1,2.5,5,10,15$ and $30 \mathrm{~g} / \mathrm{L}$. An increase in organic load till $5 \mathrm{~g} / \mathrm{L}$ showed correspondingly an increase in hydrogen production (Figure 4), which indicated the tolerance of native bacteria in acidogenic conditions. Further increase in organic load resulted in a decrease of hydrogen production (Figure 4), as a consequence of acidogenic bacteria inhibition. Generation of volatile fatty acids and variation of $\mathrm{pH}$ value of the fermentation broth showed good agreement with the hydrogen production. Increase in organic loading at the initial $\mathrm{pH}$ value of 6.4 resulted in the gradual decrease of $\mathrm{pH}$ value at the end of fermentation $(6.33,5.95,5.16,4.92,4.22$ and 4.19 for $1,2.5,5,10,15$ and $30 \mathrm{~g} / \mathrm{L}$, respectively). Furthermore, increase in organic loading resulted in higher concentrations of total volatile fatty acids, reaching 5611 and 5568

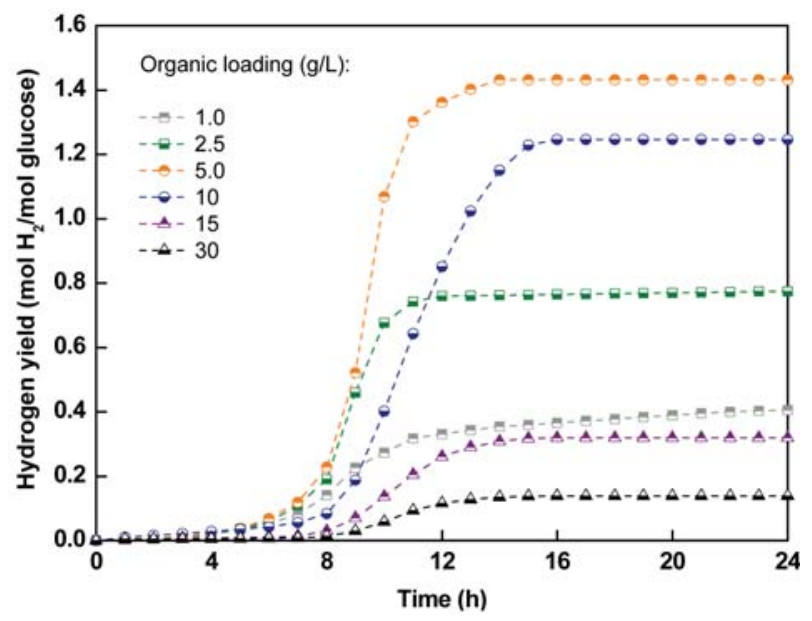

Figure 4. Hydrogen yields for different organic loadings. Lines show trends. $\mathrm{mg} / \mathrm{L}$ for loadings of 15 and $30 \mathrm{~g} / \mathrm{L}$, respectively. Similar concentrations of total volatile fatty acids measured for these organic loadings could be attributed to process inhibition due to high concentrations of volatile fatty acids formed during the fermentation.

\section{4. Influence of Carbon Source on Hydrogen Production}

Influence of carbon source on biohydrogen production by mixed anaerobic consortia was studied using different mono- and disaccharides. Among monosaccharides, we selected three hexose sugars (fructose, glucose and galactose) and two pentose sugars (ribose and xylose). It is known that the theoretical yield of hexose fermentation to acetic acid gives $4 \mathrm{~mol}$ of $\mathrm{H}_{2} / \mathrm{mol}$ hexose, while fermentation to butyric acid gives $2 \mathrm{~mol} \mathrm{H}_{2} / \mathrm{mol}$ hexose. On the other hand, theoretical hydrogen yield on pentose sugars peaks to $3.33 \mathrm{~mol} \mathrm{H}_{2} / \mathrm{mol}$ pentose in the case of acetic acid, and to $1.67 \mathrm{~mol} \mathrm{H}_{2} / \mathrm{mol}$ pentose when butyric acid is produced as the fermentation by-product. ${ }^{24}$

The obtained results demonstrate that the mixed anaerobic culture was able to convert selected substrates to hydrogen with different efficiency. Using various mono- and disaccharides, glucose and sucrose exhibited the highest hydrogen yield, respectively. As shown in Table 3, sucrose was determined to have cumulative hydrogen production of $370 \mathrm{NmL}$, hydrogen production rate of $67 \mathrm{Nm}$ $\mathrm{L} / \mathrm{h}$ and the shortest lag-phase time $(7.0 \mathrm{~h})$ among all substrates examined in the present study. The maximum hydrogen production rate $(82 \mathrm{NmL} / \mathrm{h})$ and the maximum hydrogen yield $\left(1.44 \mathrm{~mol} \mathrm{H}_{2} / \mathrm{mol}\right)$ were in the given range of operating and reaction conditions obtained from glucose. The lowest cumulative hydrogen production was exhibited by ribose $(205 \mathrm{NmL})$ and xylose $(177 \mathrm{NmL})$, having longer lag-phase time (11.1 and $12.5 \mathrm{~h}$, respectively) than other substrates. We believe that the complexity of metabolic pathways and the involvement of various enzymes in the fermentation of pentose sugars could cause lower hydrogen production and lead to prolonged lag-phase time. Furthermore, poor hydrogen yield could be due to lower affinity of substrate specific symporters, which means that substrate uptake could represent a rate-limiting step in the process. ${ }^{25}$

\section{5. Influence of Temperature under Controlled pH Values}

Within an appropriate range, increasing temperature may enhance the activity of hydrogen producing bacteria, thus resulting in higher hydrogen yield. On the other hand, it is well known that some essential enzymes and proteins associated with cell growth or hydrogen production may be inactivated at elevated temperatures. As one can see from Table 4, temperature exhibits a considerable effect on hydrogen production via dark fermentation pro- 
Table 3. Hydrogen production by anaerobic sludge from mono- and disaccharides.

\begin{tabular}{|c|c|c|c|c|c|c|c|}
\hline Parameter & xylose & ribose & glucose & galactose & fructose & lactose & sucrose \\
\hline Duration of lag phase (h) & $12.5 \pm 0.2$ & $11.1 \pm 0.3$ & $7.8 \pm 0.1$ & $11 \pm 0.2$ & $9.9 \pm 0.1$ & $8.6 \pm 0.1$ & $7.0 \pm 0.2$ \\
\hline Cumulative $\mathrm{H}_{2}$ production $(\mathrm{NmL})$ & $177 \pm 15$ & $205 \pm 17$ & $345 \pm 21$ & $224 \pm 25$ & $214 \pm 18$ & $233 \pm 17$ & $370 \pm 23$ \\
\hline Maximal $\mathrm{H}_{2}$ production rate $(\mathrm{NmL} / \mathrm{h})$ & $20 \pm 3$ & $30 \pm 4$ & $82 \pm 3$ & $36 \pm 3$ & $59 \pm 2$ & $30 \pm 3$ & $67 \pm 3$ \\
\hline $\mathrm{H}_{2}$ yield (mol $\mathrm{H}_{2} /$ mol sugar) & $0.59 \pm 0.05$ & $0.69 \pm 0.06$ & $1.44 \pm 0.09$ & $0.90 \pm 0.10$ & $0.86 \pm 0.07$ & $1.78 \pm 0.12$ & $2.83 \pm 0.16$ \\
\hline
\end{tabular}

cess. At $\mathrm{pH}$ value of 6.0 that was kept constant during the entire fermentation, hydrogen yield increased till temperature of $37^{\circ} \mathrm{C}$. There was no hydrogen production observed at $40{ }^{\circ} \mathrm{C}$, while hydrogen yield again slowly increased at 45 and drastically at $55^{\circ} \mathrm{C}$. Methane production detected at $40{ }^{\circ} \mathrm{C}\left(6.9\right.$ vol. $\%$ of $\mathrm{CH}_{4}, 0.03$ vol. \% of $\left.\mathrm{H}_{2}\right)$ and low hydrogen yield measured at $45{ }^{\circ} \mathrm{C}$ (14.6 vol. \% of $\mathrm{CH}_{4}, 15.0$ vol. $\%$ of $\mathrm{H}_{2}$ ) indicate a temperature window at which hydrogen production is suppressed. The highest hydrogen yield $\left(1.48 \mathrm{~mol} \mathrm{H}_{2} / \mathrm{mol}\right.$ glucose $)$ and maximal $\mathrm{H}_{2}$ production rate $(83 \mathrm{NmL} / \mathrm{h})$ were observed at $37^{\circ} \mathrm{C}$ for $\mathrm{pH}$ value of 6.0 (Table 4). A reason for limited performance of hydrogen production between $40-45^{\circ} \mathrm{C}$ likely resides in the limited number of microorganisms that can grow within this range. ${ }^{26}$ Even though reported optimal temperature for hydrogen production was not always the same, it fell into mesophilic and thermophilic temperature range. As suggested by Ghimire et al., ${ }^{27}$ optimal incubation temperature for hydrogen production varies significantly on the type of substrate and inoculum used. In the study of Wang et al., ${ }^{28}$ the optimum conditions for hydrogen production from sucrose-rich wastewater were reported to be: $\mathrm{pH}=5.5, \mathrm{~T}=35.1{ }^{\circ} \mathrm{C}$ and $\mathrm{c}($ sucrose $)=26 \mathrm{~g} / \mathrm{L}$. In another study, ${ }^{29}$ the authors observed the highest hydrogen production at $\mathrm{pH}=4.5$ and $\mathrm{T}=37^{\circ} \mathrm{C}$, with rice slurry containing $5.5 \mathrm{~g} / \mathrm{L}$ of carbohydrate. Furthermore, Wongthanate et al. ${ }^{30}$ reported higher hydrogen production from coconut milk wastewater for mesophilic $\left(0.28 \mathrm{LH}_{2} / \mathrm{L}\right)$

Table 4. Influence of temperature on hydrogen production under controlled $\mathrm{pH}$ values.

\begin{tabular}{llccc}
\hline $\begin{array}{l}\text { T } \\
\left({ }^{\circ} \mathbf{C}\right)\end{array}$ & $\begin{array}{l}\text { pH } \\
\text { value } \\
(/)\end{array}$ & $\begin{array}{c}\text { Lag } \\
\text { stage } \\
(\mathbf{h})\end{array}$ & $\begin{array}{c}\mathbf{H}_{\mathbf{2}} \text { yield } \\
\left(\mathbf{m o l} \mathbf{H}_{2} /\right. \\
\text { mol glucose) }\end{array}$ & $\begin{array}{c}\text { Maximal } \mathbf{H}_{2} \\
\text { production rate } \\
(\mathbf{N m L / h})\end{array}$ \\
\hline 24 & 6 & $10.9 \pm 0.2$ & $0.25 \pm 0.08$ & $1 \pm 1$ \\
30 & 6 & $9.12 \pm 0.2$ & $0.52 \pm 0.06$ & $9 \pm 1$ \\
37 & 5 & $8.65 \pm 0.3$ & $0.95 \pm 0.11$ & $10 \pm 4$ \\
& 5.5 & $7.96 \pm 0.2$ & $1.32 \pm 0.06$ & $67 \pm 3$ \\
& 6 & $7.68 \pm 0.2$ & $1.48 \pm 0.06$ & $83 \pm 3$ \\
& 6.5 & $6.92 \pm 0.1$ & $1.15 \pm 0.07$ & $33 \pm 2$ \\
40 & 6 & $6.85 \pm 0.2$ & $*$ & $*$ \\
45 & 6 & $6.42 \pm 0.1$ & $0.23 \pm 0.15$ & $7 \pm 3$ \\
55 & 5 & $8.41 \pm 0.4$ & $0.47 \pm 0.13$ & $5 \pm 3$ \\
& 5.5 & $6.28 \pm 0.2$ & $0.83 \pm 0.07$ & $34 \pm 2$ \\
& 6 & $5.69 \pm 0.1$ & $1.04 \pm 0.08$ & $55 \pm 3$ \\
& 6.5 & $4.91 \pm 0.1$ & $0.65 \pm 0.08$ & $23 \pm 3$ \\
\hline
\end{tabular}

*Methane production was observed only. over thermophilic $\left(0.16 \mathrm{LH}_{2} / \mathrm{L}\right)$ temperature conditions. On the other hand, Valdez-Vazquez et al. ${ }^{31}$ obtained better performance of anaerobic hydrogen reactors treating an organic fraction of municipal solid waste in the thermophilic range $\left(55^{\circ} \mathrm{C}\right)$ compared to corresponding mesophilic ones $\left(35^{\circ} \mathrm{C}\right)\left(360\right.$ vs. $\left.165 \mathrm{NmL} \mathrm{H}_{2} / \mathrm{g} \mathrm{VS}_{\text {rem }}\right)$.

\section{6. Influence of Mixing Intensity}

Partial pressure of hydrogen in a fermentation broth is reported to inhibit hydrogen production by hydrogenogenic bacteria, as high hydrogen concentrations suppress hydrogen production and cause shift towards the production of reduced metabolites, such as lactic acid, ethanol, acetone, butanol etc. ${ }^{32}$ Therefore, different techniques that lower hydrogen partial pressure in the fermentation broth have been applied (e.g. mixing and gas sparging in the headspace). In the present study, we observed a minor effect of different mixing intensities on hydrogen yield being in the range of $1.45-1.66 \mathrm{~mol} \mathrm{H}_{2} / \mathrm{mol}$ glucose (Table 5 ). We could observe the highest hydrogen yield at minimal mixing intensity, when the Reynolds number was set to 500. It seems that adequate liquid-gas transfer of hydrogen produced by microorganisms occurred already at low mixing intensity, while at no mixing a higher volume of hydrogen was trapped in the fermentation broth, consequently lowering the hydrogen yield. Analysis of volatile fatty acids produced at the end of fermentation showed that mixing intensity influences the distribution of soluble fermentation products. Considering the results obtained in the transitional mixing regimes at Reynolds numbers between 500 and 10.000, the increase of mixing intensity caused an increase in lactic acid formation, and decrease in acetic and butyric acid production, which in turn resulted in decreasing hydrogen yields.

\section{7. Optimal Parameters for Hydrogen and/or Volatile Fatty Acids Production}

The added value of $\mathrm{H}_{2}$ and volatile fatty acids which are products of dark fermentation can, if treated by appropriate techniques, be synthesized in a broad range of useful chemicals. By this, $\mathrm{H}_{2}$ could be used as a fuel in fuel cells or gas turbines, while extracted volatile fatty acids can be reduced to liquid fuel surrogates (propanol or butanol), converted into lipids, or used for biohydrogen or bioelectricity production in microbial fuel cells. ${ }^{33-35}$ It is therefore important to define conditions, at which diffe- 
Table 5. Influence of mixing intensity on volatile fatty acids distribution (HSa, succinic; HLac, lactic; HFr, formic; HAc, acetic, HMal, malic; HPr, propionic; HBu, butyric acid) and hydrogen yield.

\begin{tabular}{lrrrrrrrc}
\hline $\begin{array}{l}\text { Reynolds } \\
\text { number }\end{array}$ & HSa & HLac & HFr & HAc & HMal & HPr & HBu & $\begin{array}{c}\mathbf{H}_{2} \text { yield } \\
\text { (mol } \mathbf{H}_{2} / \text { mol glucose) }\end{array}$ \\
\hline 0 & 111 & 7 & 47 & 461 & 10 & 72 & 947 & 1.45 \\
500 & 120 & 12 & 32 & 485 & 9 & 68 & 920 & 1.66 \\
1.000 & 100 & 162 & 101 & 436 & 8 & 85 & 871 & 1.57 \\
2.000 & 99 & 263 & 45 & 403 & 6 & 49 & 824 & 1.52 \\
10.000 & 87 & 329 & 14 & 380 & 6 & 42 & 790 & 1.47 \\
\hline
\end{tabular}
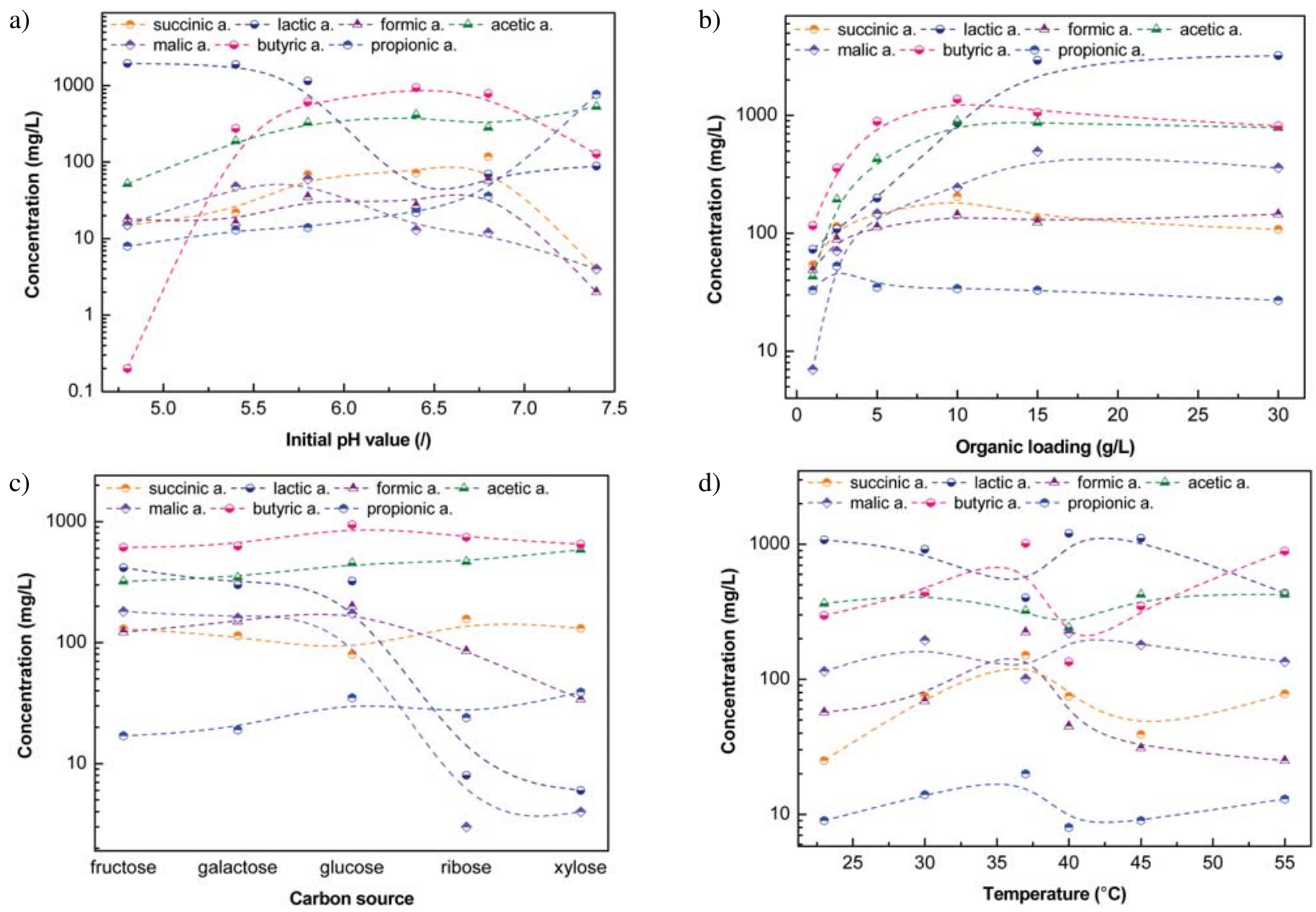

e)
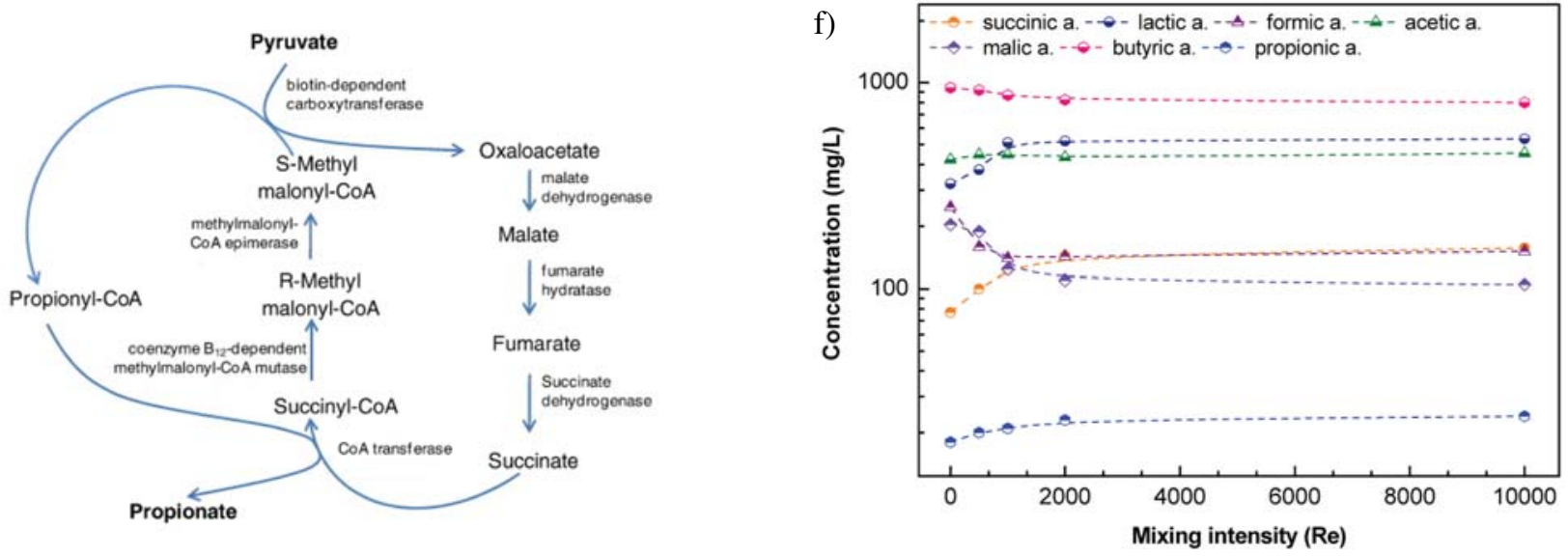

Figure 5. Concentration of VFA as a function of initial $\mathrm{pH}$ value (a), organic loading (b), carbon source (c), temperature (d) and mixing intensity (e). Lines show trends. Schematic representatation of propionate production in Propionibacterium freudenreichii (f). ${ }^{36}$ 
rent volatile fatty acids are produced in highest possible quantities during the dark fermentation process. In our experiments, we discovered that the highest concentrations of butyric, acetic, lactic, propionic and formic acid, as well as acids that originate from TCA cycle were obtained at considerably different conditions (Figure 5). As expected, the optimal conditions for butyric and acetic acid production were similar for all tested parameters. The highest obtained concentrations for butyric $(1370 \mathrm{mg} / \mathrm{L})$ and acetic acid $(891 \mathrm{mg} / \mathrm{L})$ were in the case of organic overloading at $30 \mathrm{~g} / \mathrm{L}$, with lactic acid $(3214 \mathrm{mg} / \mathrm{L})$ as dominant metabolic product.

Among metabolic pathways that occur in microorganisms, TCA cycle that exists in almost all living organisms is often regarded as crucial. Chemical compounds in the TCA cycle include citric acid, á-ketoglutaric acid, succinic acid, fumaric acid, malic acid and oxaloacetate. Results presented in this study demonstrate that mixed anaerobic consortia used in the performed experiments is capable of producing higher quantities of malic, succinic as well as propionic acid, which is produced from succinic acid by bacteria from genus Propionibacterium (Figure $5 \mathrm{f})$. High concentration of propionic acid $(771 \mathrm{mg} / \mathrm{L})$ was observed at $\mathrm{pH}$ value of 7.4 , while succinic $(206 \mathrm{mg} / \mathrm{L})$ and malic acid $(495 \mathrm{mg} / \mathrm{L})$ concentrations were highest at organic loading of 10 and $15 \mathrm{~g} / \mathrm{L}$, respectively.

\section{Conclusions}

Among examined substrates, glucose was shown as the most preferred carbon source for biohydrogen production. All tested parameters with the exception of mixing intensity were shown to have significant effects on hydrogen production process. Under the optimal conditions (at initial $\mathrm{pH}$ value of 6.4 , glucose concentration of $5 \mathrm{~g} / \mathrm{L}$ and temperature of $37{ }^{\circ} \mathrm{C}$ ), hydrogen production rate and hydrogen yield were $91 \mathrm{NmL} / \mathrm{h}$ and $1.55 \mathrm{~mol} \mathrm{H}_{2} / \mathrm{mol}$ glucose, respectively. It was revealed that optimal hydrogen yield was associated with butyric and acetic acid production, while low hydrogen yields were observed when lactic acid prevailed among soluble metabolites.

\section{Acknowledgements}

The authors gratefully acknowledge Prof. Romana Marinšek Logar for timely suggestions and help in the experimental design as well as the financial support of the Ministry of Education, Science and Sport of the Republic of Slovenia through Research program P2-0150.

\section{References}

1. K. Y. Show, D. J. Lee, J. S. Chang. Bioresour. Technol. 2011 , 102, 8524-8533.

http://dx.doi.org/10.1016/j.biortech.2011.04.055

2. M. E. Nissilä, C. H. Lay, J. A. Puhakka. Biomass. Bioenerg. 2014, 67, 145-159.

http://dx.doi.org/10.1016/j.biombioe.2014.04.035

3. J. Masset, M. Calusinska, C. Hamilton, S. Hiligsmann, B. Joris, A. Wilmotte, P. Thonart. Biotechnol. Biofuels. 2012, 5 , 35. http://dx.doi.org/10.1186/1754-6834-5-35

4. L. T. Angenent, K. Karim, M. H. Al-Dahhan, B. A. Wrenn, R. Domíguez-Espinosa. Trends. Biotechnol. 2004, 22, 477485. http://dx.doi.org/10.1016/j.tibtech.2004.07.001

5. S. Ray, S. J. Reaume, J. A. Lalman. Int. J. Hydrogen. Energ. 2010, 35, 5332-5342.

http://dx.doi.org/10.1016/j.ijhydene.2010.03.040

6. L. Guo, X. M. Li, X. Bo, Q. Yang, G. M. Zeng, D. X. Liao, J. J. Liu. Bioresour. Technol. 2008, 99, 3651-3658. http://dx.doi.org/10.1016/j.biortech.2007.07.026

7. N. Q. Ren, W. Q. Guo, X. J. Wang, W. S. Xiang, B. F. Liu, X. Z. Wang, J. Ding, Z. B. Chen. Int. J. Hydrogen. Energ. 2008, $33,4318-4324$.

http://dx.doi.org/10.1016/j.ijhydene.2008.06.003

8. G. Cai, B. Jin, P. Monis, C. Saint. Biotechnol. Adv. 2011, 29, 375-387.

http://dx.doi.org/10.1016/j.biotechadv.2011.02.001

9. L. Jianzheng, R. Nanqi, L. Baikun, Q. Zhi, H. Junguo. Bioresour. Technol. 2008, 99, 6528-6537. http://dx.doi.org/10.1016/j.biortech.2007.11.072

10. X. Gómez, M. J. Cuetos, J. I. Prieto, A. Morán. Renew. Energy. 2009, 34, 970-975. http://dx.doi.org/10.1016/j.renene.2008.08.011

11. L. Zhang, L. Jianzheng, Q. Ban, J. He, K. J. Ajay. J. Microbiol. Biotechnol. 2012, 22, 668-673. http://dx.doi.org/10.4014/jmb.1110.10076

12. F. R. Hawkes, R. Dinsdale, D. L. Hawkes, I. Hussy. Int. J. Hydrogen. Energ. 2002, 27, 1339-1347. http://dx.doi.org/10.1016/S0360-3199(02)00090-3

13. S. K. Khanal, W. H. Chen, L. Li, S. Sung. Int. J. Hydrogen. Energ. 2004, 29, 1123-1131.

14. F. D. Faloye, E. B. Gueguim Kana, S. Schmidt. Int. J. Hydrogen. Energ. 2014, 39, 5607-5616. http://dx.doi.org/10.1016/j.ijhydene.2014.01.163

15. O. Mizuno, R. Dinsdale, F. R. Hawkes, D. L. Hawkes, T. Noike. Bioresour. Technol. 2000, 73, 59-65. http://dx.doi.org/10.1016/S0960-8524(99)00130-3

16. G. L. Tang, J. Huang, Z. J. Sun, Q. Q. Tang, C. H. Yan, G. Q. Liu. J. Biosci. Bioeng. 2008, 106, 80-87. http://dx.doi.org/10.1263/jbb.106.80

17. X. M. Guo, E. Trably, E. Latrille, H. Carrere, J. P. Steyer. Int. J. Hydrogen. Energ. 2014, 39, 7476-7485. http://dx.doi.org/10.1016/j.ijhydene.2013.08.079

18. J. T. Kraemer, D. M. Bagley. Water. Sci. Technol. 2008, 57, 681-685. http://dx.doi.org/10.2166/wst.2008.066

19. B. Si, J. Li, B. Li, Z. Zhu, R. Shen, Y. Zhang, Z. Liu. Int. J. 
Hydrog. Energ. 2015, 40, 11414-11421. http://dx.doi.org/10.1016/j.ijhydene.2015.04.035

20. N. C. M. Saady, S. Chaganti, D. Heath, J. A. Lalman. Int. J. Hydrog. Energ. 2012, 37, 4036-4045. http://dx.doi.org/10.1016/j.ijhydene.2011.11.085

21. Y. Zhu, S. T. Yang. J. Biotechnol. 2004, 110, 143-157. http://dx.doi.org/10.1016/j.jbiotec.2004.02.006

22. X. Li, Y. Chen, S. Zhao, D. Wang, X. Zheng, J. Luo. Biochem. Eng. J. 2014, 84, 28-35. http://dx.doi.org/10.1016/j.bej.2013.12.020

23. M. Koussémon, Y. Combet-Blanc, B. Olliver. Curr. Microbiol. 2003, 46, 141-145. http://dx.doi.org/10.1007/s00284-002-3839-x

24. P. Abdeshahian, N. K. N. Al-Shorgani, N. K. M. Salih, H. Shukor, A. Kadier, A. A. Hamid, M. S. Kalil, Int. J. Hydrogen. Energ. 2014, 39, 12524-12531. http://dx.doi.org/10.1016/j.ijhydene.2014.05.081

25. H. Xiao, Y. Gu, Y. Ning, Y. Yang, W. J. Mitchell, W. Jiang, S. Yang. Appl. Environ. Microbiol. 2011, 77, 7886-7895. http://dx.doi.org/10.1128/AEM.00644-11

26. C. P. L. Grady, G. T. Daiger, H. C. Lim. Biological Wastewater Treatment, Dekker, New York, 1999, pp 630-632.

27. A. Ghimire, L. Frunzo, F. Pirozzi, E. Trably, R. Escudie, P. M. L. Lens, G. Esposito. Appl. Energy. 2015, 144, 73-95. http://dx.doi.org/10.1016/j.apenergy.2015.01.045

28. G. Wang, Y. Mu, H. Q. Yu. Biochem. Eng. J. 2005, 23, 175184. http://dx.doi.org/10.1016/j.bej.2005.01.002
29. H. H. P. Fang, C. Li, T. Zhang. Int. J. Hydrogen. Energ. 2006, 31, 683-692. http://dx.doi.org/10.1016/j.ijhydene.2005.07.005

30. J. Wongthanate, K. Chinnacotpong, M. Khumpong. Int. J. Ener. Environ. Engin. 2014, 5, 1-6. http://dx.doi.org/10.1186/2251-6832-5-1

31. I. Valdez-Vazquez, E. Ríos-Leal, F. Esparza-García, F. Cecchi, H. M. Poggi-Varaldo. Int. J. Hydrogen. Energ. 2005, 30, 1383-1391. http://dx.doi.org/10.1016/j.ijhydene.2004.09.016

32. D. B. Levin, L. Pitt, M. Love. Int. J. Hydrogen. Energ. 2004, 29, 173-185. http://dx.doi.org/10.1016/S0360-3199(03)00094-6

33. Y. Chen, J. Luo, Y. Yan, L. Feng. Appl. Energy. 2013, 102, 1197-1204. http://dx.doi.org/10.1016/j.apenergy.2012.06.056

34. E. Brenna, F. Cannavale, M. Crotti, F. Parmeggiani, A Romagnolo, F. Spina, G. C. Varese. J. Mol. Catal. B: Enzym. 2015, 116, 83-88. http://dx.doi.org/10.1016/j.molcatb.2015.03.010

35. S. Vajpeyi, K. Chandran. Bioresour. Technol. 2015, 188, 49-55. http://dx.doi.org/10.1016/j.biortech.2015.01.099

36. A. Thierry, SM. Deutch, H. Falentin, M. Dalmasso, F. J. Cousin, G. Jan. Int J Food Microbiol. 2011, 149, 19-27 http://dx.doi.org/10.1016/j.ijfoodmicro.2011.04.026

\section{Povzetek}

Vodik se pogosto omenja kot gorivo prihodnosti, saj ima na enoto mase visoko kemijsko energijo, poleg tega pa med njegovim zgorevanjem nastaja le voda. $\mathrm{V}$ zadnjem času se kot procesu z nizko ogljično bilanco posebno pozornost posveča fermentativni produkciji vodika. V tej raziskavi smo proces produkcije vodika optimizirali na osnovi različnih okoljskih in procesnih dejavnikov - vir ogljika (mono in disaharidi), $\mathrm{pH}$ vrednost, temperatura, organska obremenitev

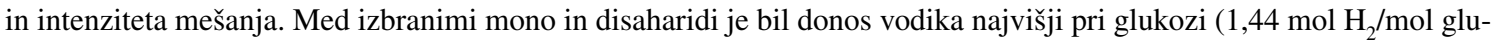
koze). Nadaljnje preučevanje izbranih parametrov je pokazalo najvišji donos vodika $\left(1,55 \mathrm{~mol} \mathrm{H}_{2} / \mathrm{mol}_{\text {glukoze})}\right.$ pri začetni pH vrednosti 6,4 , temperaturi $37{ }^{\circ} \mathrm{C}$ in organski obremenitvi $5 \mathrm{~g} / \mathrm{L}$. Na drugi strani je bil nižji donos vodika pri ostalih obratovalnih in reakcijskih pogojih povezan s preusmeritvijo metabolnih poti produkcije butanojske in ocetne kisline $\mathrm{v}$ produkcijo mlečne kisline. Zbrani rezultati tako predstavljajo pomembno osnovo za optimizacijo procesa temne fermentacije, kot tudi produkcijo vodika na industrijskem nivoju. 